\title{
F-19848 A, a Novel Inhibitor of Hyaluronic Acid Binding to Cellular Receptor CD44
}

\author{
Yuki Hirota-Takahata, Hosami Harada, Isshin Tanaka, Tomoko Nakata, \\ Mutsuo Nakajima, Masaaki Takahashi
}

Received: July 23, 2007 / Accepted: October 2, 2007

(C) Japan Antibiotics Research Association

\begin{abstract}
In the course of our screening for inhibitors of hyaluronic acid (HA) binding to cellular receptor CD44, a novel inhibitor, F-19848 A, was isolated from the cultured broth of the fungus strain Dacrymyces sp. SANK 20204. This compound inhibited the binding of CD44 and HA with an $\mathrm{IC}_{50}$ value of $23.5 \mu \mathrm{M}$ and CD44-dependent HA degradation was inhibited with an $\mathrm{IC}_{50}$ value of $98.6 \mu \mathrm{M}$ in a cell-based assay. The structure was elucidated by physicochemical properties, analysis of spectral data, and decomposition experiments.
\end{abstract}

Keywords F-19848 A, hyaluronic acid, CD44, inhibitor

\section{Introduction}

Hyaluronic acid (HA) is a high molecular-weight polysaccharide that is present in the extracellular and pericellular matrices of most tissues. It has been well established that HA is important as a structural molecule that assists in tissue hydration and in biophysical properties such as resilience, and forms a template to which matrix proteins attach and form extracellular structural complexes [1 6].

CD44 is the most common HA receptor and is expressed abundantly on many cell types [7 12]. It has been suggested that HA is catabolized in a CD44-dependent manner [13 15]. Our recent observation also revealed that CD44 has critical roles in the intracellular and extracellular catabolism of HA mediated by hyaluronidase-1 (Hyal-1) and hyaluronidase-2 (Hyal-2), respectively [16]. In addition, it has been shown that the signaling functions of HA are mediated by CD44 [17]. Consequently, inhibition of HA binding to CD44 could interfere with the turnover and/or function of HA, and might be of therapeutic value in the treatment of various diseases, including osteoarthritis, rheumatoid arthritis and cancer. We have established a convenient screening method for inhibitors of HA binding to CD44 [18], and subsequently isolated novel CD44 inhibitors, F-16438s, from the cultured broth of Gloeoporus dichrous SANK 30502 [19].

In the course of our screening for inhibitors of HA binding to CD44, another novel inhibitor, F-19848 A, was isolated from the cultured broth of Dacrymyces sp. SANK 20204 (Figs. 1, 2). Here we report the production, isolation procedures, physico-chemical properties, structural elucidation and biological activities of F-19848 A.

\section{Results and Discussion}

\section{Producing Organism}

The producing strain SANK 20204 was isolated from the spore print of fresh basidiocarps collected in Shiga Prefecture, Japan. As this basidiomycete could not be characterized by cultural features, dried basidiocarps were needed for identification. The mycological properties were as follows (Fig. 2).
M. Takahashi (Corresponding author), H. Harada, T. Nakata: Exploratory Research Laboratories II, Daiichi-Sankyo Co., Ltd., 1-16-13, Kitakasai, Edogawa-ku, Tokyo 134-8630, Japan,

E-mail: takahashi.masaaki.rs@daiichisankyo.co.jp
Y. Hirota-Takahata, I. Tanaka, M. Nakajima: Advanced Technology Research Laboratories, Daiichi-Sankyo Co., Ltd., 1-258, Hiromachi, Shinagawa-ku, Tokyo 140-8710, Japan 


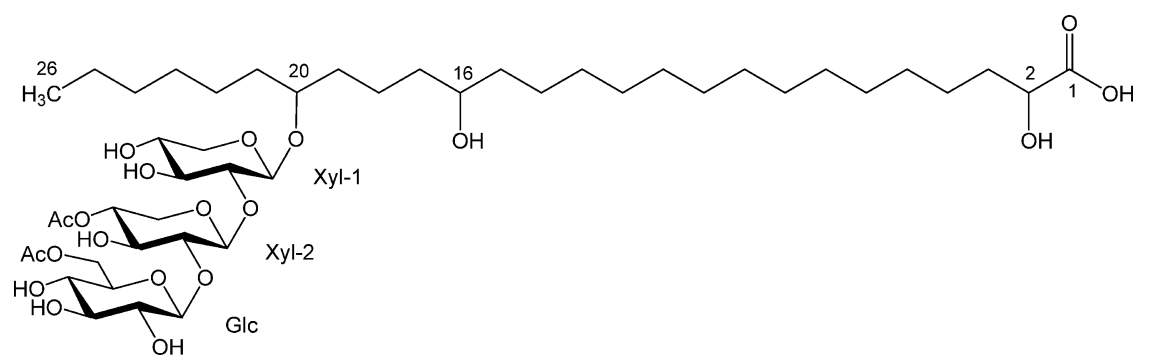

Fig. 1 Structure of F-19848 A (1).

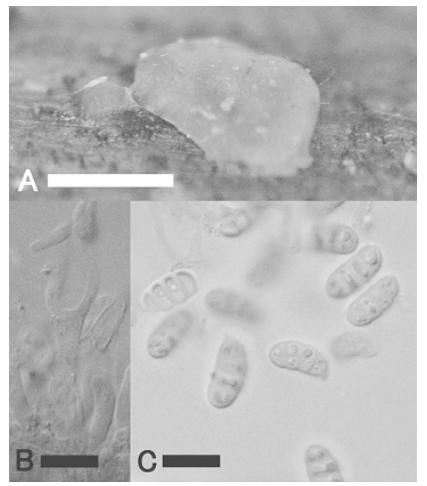

Fig. 2 Morphological characteristics of Dacrymyces sp. SANK 20204.

\section{A, Basidiocarp; B, Basidium; C, Basidiospores.}

Scales: $A=0.5 \mathrm{~mm} ; B \sim C=10 \mu \mathrm{m}$.

The basidiocarps were gregarious on the decaying twig, $0.6 \sim 6 \mathrm{~mm}$ in diameter, low pulvinate to plate-shaped, softly gelatinous and pale yellow. The basidia were $20 \sim 33 \times 4 \sim 6 \mu \mathrm{m}$ (excluding sterigmata), Y-shaped, without clamp connections at the base. The sterigmata were up to $18 \times 3 \mu \mathrm{m}$. The basidiospores were $9 \sim 15 \times 5 \sim 7 \mu \mathrm{m}$, with $(0 \sim) 3$ septa, elliptic-cylindric, slightly curved, thick-walled and smooth. Conidia were not observed in the basidiocarps or in the culture.

The above characteristics of the basidiocarps corresponded with the description of the genus Dacrymyces [20]. Although the strain SANK 20204 was similar to Dacrymyces stillatus Nees: Fr., it differed in that there was an absence of conidia. Hence, the strain was identified as Dacrymyces sp.

This strain has been deposited at the National Institute of Advanced Industrial Science and Technology, Japan, as Dacrymyces sp. SANK 20204 under the accession number FERM BP-10124.

\section{Fermentation}

The growth of Dacrymyces sp. SANK 20204 on an agar slant $\left(1 \mathrm{~cm}^{3}\right)$ was homogenized with sterile water $(3.0 \mathrm{ml})$ and the entire homogenate was transferred into a $100-\mathrm{ml}$
Erlenmeyer flask containing $30 \mathrm{ml}$ of a sterilized primary seed medium composed of glucose $0.4 \%$, malt extract $1.0 \%$, yeast extract $0.4 \%$, agar $0.3 \%$ and Disfoam CB-442 (Nippon Yushi Co.) $0.005 \%$. The flask was incubated at $23^{\circ} \mathrm{C}$ for 7 days on a rotary shaker at $210 \mathrm{rpm}$. The primary seed culture $(15 \mathrm{ml})$ was transferred into a $500-\mathrm{ml}$ AGRIFLEX bag (Fujimori Kogyo Co., Ltd.) containing a sterilized production medium composed of grains of barley $64 \mathrm{~g}$, mannitol $1.0 \mathrm{~g}$, sodium L-(+)-glutamate monohydrate $0.5 \mathrm{~g}$, yeast extract $0.5 \mathrm{~g}, \mathrm{KH}_{2} \mathrm{PO}_{4} 0.1 \mathrm{~g}, \mathrm{MgSO}_{4} \cdot 7 \mathrm{H}_{2} \mathrm{O}$ $0.1 \mathrm{~g}$ and distilled water $100 \mathrm{ml}$. The fermentation was carried out at $23^{\circ} \mathrm{C}$ for 14 days by stationary cultivation.

\section{Isolation}

An equal amount of $\mathrm{Me}_{2} \mathrm{CO}$ was added to the culture (3.0 liters). The extract was filtered with the assistance of Celite 545 (Celite Co.) and concentrated to remove the $\mathrm{Me}_{2} \mathrm{CO}$. After the $\mathrm{pH}$ of the concentrate was adjusted to 3.0 with $6 \mathrm{M} \mathrm{HCl}$, an active compound was extracted with EtOAc. The organic layer was washed with brine, dried over anhydr. $\mathrm{Na}_{2} \mathrm{SO}_{4}$, and concentrated to give an oily substance $(7.5 \mathrm{~g})$. The substance was dissolved in $10 \mathrm{ml}$ of $\mathrm{MeCN}$ $0.3 \%$ triethylamine-phosphate (TEAP) buffer at $\mathrm{pH} 3.0$ $(2: 3)$ and subsequently subjected to a Cosmosil column (Cosmosil 140C18-OPN, Nacalai Tesque, Inc. $250 \mathrm{ml}$ ). The column chromatography was performed by stepwise elution using MeCN-0.3\% TEAP buffer at $\mathrm{pH} 3.0$ in the ratios of $2: 3$ (1 liter), $1: 1$ (0.5 liters) and $11: 9$ (1 liter).

A fraction of the 11:9 step containing biological activity was concentrated to remove the $\mathrm{MeCN}$ and adjusted $\mathrm{pH}$ to 3.0 with $6 \mathrm{M} \mathrm{HCl}$. The active compound was extracted into EtOAc, which was washed with brine and dried over anhydr. $\mathrm{Na}_{2} \mathrm{SO}_{4}$. The organic layer was concentrated to dryness and the resulting residue was subjected to preparative HPLC using an ODS column (Waters SYMMETRY C18, 19 i.d. $\times 100 \mathrm{~mm}$ ) with $\mathrm{MeCN}$ $0.6 \%$ TEAP buffer at $\mathrm{pH} 3.0(3: 2)$ at a flow rate of $6.0 \mathrm{ml} /$ minute. The fraction containing an active compound was de-salted by EtOAc extraction as described above to afford pure F-19848 A (1) as a white powder (182 mg). 
Physico-chemical Properties and Structural Elucidation

The physico-chemical properties of $\mathbf{1}$ are summarized in Table 1.

The molecular formula of $\mathbf{1}$ was determined to be $\mathrm{C}_{46} \mathrm{H}_{82} \mathrm{O}_{20}\left[\mathrm{~m} / \mathrm{z}\right.$, found $953.5279(\mathrm{M}-\mathrm{H})^{-}$, calcd. 953.5321 for $\mathrm{C}_{46} \mathrm{H}_{81} \mathrm{O}_{20}$ ] by negative ion ESI-TOFMS.

The ${ }^{1} \mathrm{H}$ - and ${ }^{13} \mathrm{C}$-NMR spectral data of $\mathbf{1}$ obtained in methanol- $d_{4}$ are summarized in Table 2. In the ${ }^{1} \mathrm{H}-\mathrm{NMR}$ spectrum of 1 , signals from two acetyl groups $(\delta 2.06$ and $2.11)$ and glycosyl groups $(\delta 3.1 \sim 4.75)$ were observed. The alkyl proton signals were a complex of overlapped
Table 1 Physico-chemical properties of F-19848 A (1)

\begin{tabular}{ll}
\hline Appearance & White powder \\
Molecular formula & $\mathrm{C}_{46} \mathrm{H}_{82} \mathrm{O}_{20}$ \\
HR-MS $(\mathrm{m} / \mathrm{z})$ & \\
Found: & $953.5279(\mathrm{M}-\mathrm{H})^{-}$ \\
Calcd.: & $953.5321\left(\right.$ for $\left.\mathrm{C}_{46} \mathrm{H}_{81} \mathrm{O}_{20}\right)$ \\
{$[\alpha]_{D}^{25}$} & $-28^{\circ}(c 1.0, \mathrm{MeOH})$ \\
UV $\lambda_{\max }^{\mathrm{MeOH}} \mathrm{nm}(\varepsilon)$ & End absorption \\
IR $v_{\max }(\mathrm{KBr}) \mathrm{cm}^{-1}$ & $3409,2926,2854,1737,1369$, \\
& $1244,1081,1051$ \\
\hline
\end{tabular}

Table $2{ }^{1} \mathrm{H}$ - and ${ }^{13} \mathrm{C}-\mathrm{NMR}$ signal assignments of $\mathbf{1}$ in methanol- $d_{4}$

\begin{tabular}{|c|c|c|c|}
\hline Position & & $\delta_{\mathrm{C}}$ & $\delta_{\mathrm{H}}$ \\
\hline \multirow[t]{5}{*}{$\mathrm{Xyl}-1$} & $1^{\prime}$ & 102.5 & $4.38(1 \mathrm{H}, \mathrm{d}, 7.0 \mathrm{~Hz})$ \\
\hline & $2^{\prime}$ & 84.6 & $3.25(1 \mathrm{H})^{\mathrm{a}}$ \\
\hline & $3^{\prime}$ & 77.2 & $3.51(1 \mathrm{H})^{\mathrm{a}}$ \\
\hline & $4^{\prime}$ & 70.6 & $3.51(1 \mathrm{H})^{\mathrm{a}}$ \\
\hline & $5^{\prime}$ & 66.6 & $3.18(1 \mathrm{H})^{\mathrm{a}}, 3.83(1 \mathrm{H})^{\mathrm{a}}$ \\
\hline \multirow[t]{7}{*}{$\mathrm{Xyl}-2$} & $1^{\prime \prime}$ & 104.3 & $4.62(1 \mathrm{H}, \mathrm{d}, 7.3 \mathrm{~Hz})$ \\
\hline & $2^{\prime \prime}$ & 83.5 & $3.52(1 \mathrm{H})^{\mathrm{a}}$ \\
\hline & $3^{\prime \prime}$ & 74.4 & $3.80(1 \mathrm{H})^{\mathrm{a}}$ \\
\hline & $4^{\prime \prime}$ & 72.9 & $4.71(1 \mathrm{H})^{\mathrm{a}}$ \\
\hline & $5^{\prime \prime}$ & 63.5 & $3.22(1 \mathrm{H})^{\mathrm{a}}, 3.97(1 \mathrm{H}, \mathrm{dd}, 5.5,11.7 \mathrm{~Hz})$ \\
\hline & 4"-OAc & 172.2 & \\
\hline & & 20.8 & $2.06(3 \mathrm{H}, \mathrm{s})$ \\
\hline \multirow[t]{9}{*}{ Glc } & $1^{\prime \prime \prime}$ & 105.6 & $4.67(1 \mathrm{H}, \mathrm{d}, 7.7 \mathrm{~Hz})$ \\
\hline & $2^{\prime \prime \prime}$ & 75.7 & $3.26(1 \mathrm{H})^{\mathrm{a}}$ \\
\hline & $3^{\prime \prime \prime}$ & 77.6 & $3.37(1 \mathrm{H})^{\mathrm{a}}$ \\
\hline & $4^{\prime \prime \prime}$ & 71.2 & $3.33(1 \mathrm{H})^{\mathrm{a}}$ \\
\hline & $5^{\prime \prime \prime}$ & 75.8 & $3.53(1 \mathrm{H})^{\mathrm{a}}$ \\
\hline & $6^{\prime \prime \prime}$ & 64.5 & $4.22(1 \mathrm{H}, \mathrm{dd}, 5.5,12.0 \mathrm{~Hz})$ \\
\hline & & & $4.46(1 \mathrm{H}, \mathrm{dd}, 1.8,12.0 \mathrm{~Hz})$ \\
\hline & 6"'-OAc & 173.0 & \\
\hline & & 21.1 & $2.11(3 \mathrm{H}, \mathrm{s})$ \\
\hline \multirow[t]{12}{*}{ Fatty acid } & 1 & 178.3 & \\
\hline & 2 & 71.6 & $4.08(1 \mathrm{H}, \mathrm{dd}, 4.4,7.7 \mathrm{~Hz})$ \\
\hline & 3 & 35.5 & $1.63(1 \mathrm{H}, \mathrm{m}), 1.74(1 \mathrm{H}, \mathrm{m})$ \\
\hline & 4 & 26.2 & $1.40(2 \mathrm{H})^{\mathrm{a}}$ \\
\hline & $5 \sim 15$ & $22.4 \sim 38.4$ & $1.20 \sim 1.55^{\mathrm{a}}$ \\
\hline & 16 & 72.5 & $3.49(1 \mathrm{H})^{\mathrm{a}}$ \\
\hline & $17 \sim 19$ & $22.4 \sim 38.4$ & $1.20 \sim 1.55^{\mathrm{a}}$ \\
\hline & 20 & 80.2 & $3.61(1 \mathrm{H}, \mathrm{m})$ \\
\hline & $21 \sim 23$ & $22.4 \sim 38.4$ & $1.20 \sim 1.55^{\mathrm{a}}$ \\
\hline & $24^{b}$ & 23.8 & $1.31(2 \mathrm{H})^{\mathrm{a}}$ \\
\hline & $25^{b}$ & 33.2 & $1.30(2 \mathrm{H})^{a}$ \\
\hline & 26 & 14.6 & $0.91(3 \mathrm{H}, \mathrm{t}, 7.0 \mathrm{~Hz})$ \\
\hline
\end{tabular}

Spectra were recorded at $500 \mathrm{MHz}$ for ${ }^{1} \mathrm{H}$ and $125 \mathrm{MHz}$ for ${ }^{13} \mathrm{C}$, respectively, in methanol- $d_{4}$. Chemical shifts are referenced to TMS signal at $0.0 \mathrm{ppm}$.

a) overlapped, b) interchangeable. 
methylene or methyl signals. In the ${ }^{13} \mathrm{C}-\mathrm{NMR}$ spectrum, 40 carbon signals were observed and classified into $3 \times$ methyl, $18 \times$ methylene, $16 \times$ methine and 3 quaternary carbons.

The NMR signal assignment was accomplished mainly using DEPT, HSQC, DQFCOSY and HMBC spectra. As shown in Fig. 3 , the existence of three anomeric carbons $(\delta$ $102.5,104.3$ and 105.6) with connectivity to $O$-methine protons, and the carbon signals indicated that three sugar residues were included in the structure. Further NMR spectroscopic studies revealed the structure of di-acetylated trisaccharide moiety as $6 "-O$-acetylhexopyranosyl-( $(1 \rightarrow 2)-$ 4'-O-acetylpentopyranosyl-( $(\rightarrow 2)$-pentopyranoside. Highly complicated equivalent methylene signals in the alkyl region, three $O$-methine signals $(\delta 71.6,72.5$ and 80.2) assigned next to the methylene and the signals derived from the carboxylic acid residue in the ${ }^{1} \mathrm{H}$ - and ${ }^{13} \mathrm{C}$-NMR spectra suggested the presence of tri-hydroxylated $n$-fatty acid.

To identify the locations of three hydroxyl groups and the glycosylation site of the fatty acid, the molecule was derivatized by methylation of the free hydroxyl groups, followed by deglycosylation with methanolysis. The free hydroxyl group produced by the deglycosylation was silylated to obtain a differentially methylated-silylated derivative of F-19848 A (2). As shown in Fig. 4, the fragment ions derived from 2 in the GC-MS revealed the

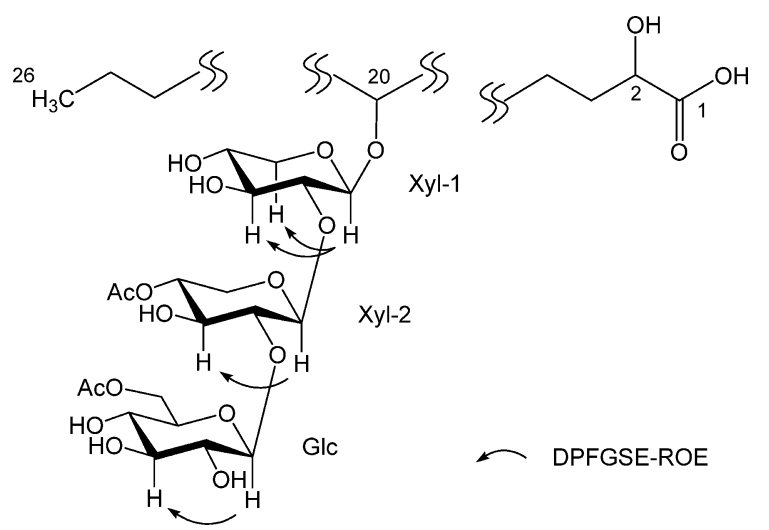

Fig. 3 Partial structures and sugar configurations of $\mathbf{1}$. structure of the hydroxyl fatty acid as 2,16,20-trihydroxy- $n$ hexacosanoic acid and the silylated site which originated from the glycosylation site was clearly assigned to C-20. Thus, the planar structure of $\mathbf{1}$ was elucidated as shown in Fig. 1.

The identification of the sugars was also performed by GC-MS analysis [21]. Pre-treatment of $\mathbf{1}$ was performed in $S$-(+)-2-butanol $/ 5.0 \% \mathrm{HCl}-\mathrm{MeOH}(1: 1)$ solution and then the resulting (+)-2-butylglycosides were silylated and analyzed. According to the results, the constitutive sugars were determined to be two moles of D-xylose and one mole of D-glucose by a comparison study with those of the authentic samples. Because of the overlap of these sugar signals and zero-crossing in the NOE term, the configurations of the anomeric positions were determined by their DPFGSE-ROE spectra (the length of the selective $180^{\circ}$ Gaussian pulse; 50 mseconds, mixing time; 600 mseconds, relaxation time; 2 seconds, gradient ratio; $11: 11: 17: 17$ ) [22]. The H-1 positions of all three sugars were selectively excited and resulted in observed correlations. In the case of Xyl-1, a correlation with H-1' was observed at the axial proton of $\mathrm{H}-5^{\prime}$. In addition, a correlation signal was clearly observed at $\mathrm{H}-3^{\prime}$ which was overlapped with other proton signals in the original ${ }^{1} \mathrm{H}$ NMR spectrum. These data indicated that the protons at $\mathrm{H}-$ $1^{\prime}, \mathrm{H}-3^{\prime}$ and $\mathrm{H}-5^{\prime}$ were of axial orientation. In the case of Xyl-2 and Glc, the signals at the H-3" and H-3"' positions of each sugar were observed as correlation signals. These data indicated that all the anomeric protons are in a 1,3diaxial relationship in each sugar. Thus, the anomeric positions of all the sugar moieties were linked in a $\beta$ configuration.

\section{Biological Activities}

The membrane fractions from a cell line stably expressing human CD44 in HEK293 (CD44/293) [16, 18] was used to determine the inhibitory activity of $\mathbf{1}$ for CD44-HA binding. The dose-dependent inhibition of CD44-HA binding by $\mathbf{1}$ is shown in Fig. $5 \mathrm{~A}$. The $\mathrm{IC}_{50}$ value of $\mathbf{1}$ for CD44-HA binding was $23.5 \mu \mathrm{M}$. Then, the effect of the compound in living cells was examined by Hyal-

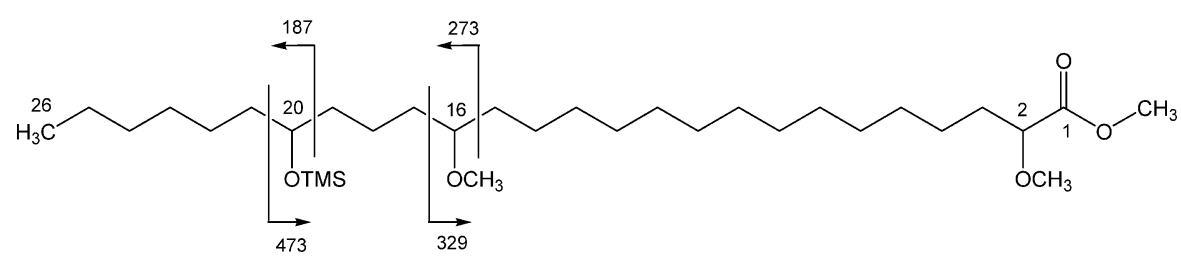

Fig. 4 Structures and the observed fragment ions $(\mathrm{m} / \mathrm{z})$ of the differentially methylated-silylated derivative of F-19848 A (2). 
(A)

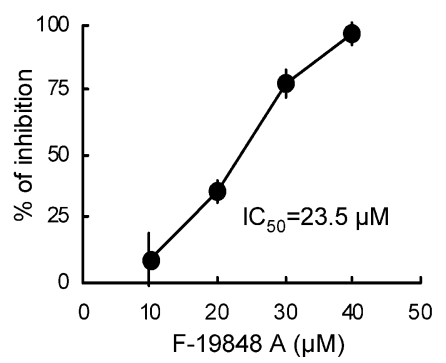

(B)

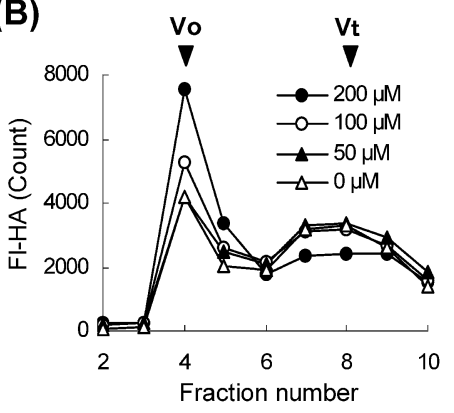

(C)

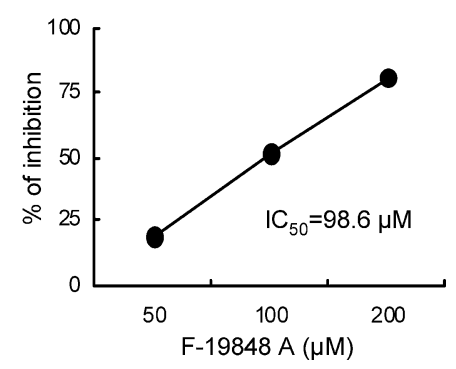

Fig. 5 Biological activities of $\mathbf{1}$.

(A) Inhibition of binding of CD44 and HA by 1. (B) Analysis of fl-HA degradation by Hyal-2/CD44/293 cells. The concentrations of added $1(0 \sim 200 \mu \mathrm{M})$ are as indicated. (C) Inhibition of CD44 functions in living cells. The \% of inhibition was determined based on the amount of $\mathrm{fl}-\mathrm{HA}$ that retained high molecular weight (eluted in fraction numbers 4 and 5 in Fig. 4B), and plotted against 1.

2/CD44/293 cells which stably express both human Hyal-2 and CD44 [16]. Hyal-2 is the somatically expressed hyaluronidase which degrades HA pericellularly, and its enzymatic activity depends on the expression of CD44 [16]. As the interaction between CD44 and fl-HA is a crucial step to initiate extracellular degradation of fl-HA by Hyal-2/CD44/293 cells [16], inhibitors for CD44-HA binding are able to interfere with the degradation of fl-HA in the conditioned medium of the cells. Fig. 5B illustrates the Sepharose CL-2B elution profiles of fl-HAs incubated with Hyal-2/CD44/293 cells in the presence of 1 $(50 \sim 200 \mu \mathrm{M})$. The degradation of fl-HA was inhibited by $\mathbf{1}$, and the amount of fl-HA with high molecular weight increased in proportion to the amounts of $\mathbf{1}$ added into the medium. The inhibition rate of fl-HA degradation was calculated based on the amount of high molecular weight fl-HA in fraction numbers 4 and 5, and is plotted in Fig. $5 \mathrm{C}$. The $\mathrm{IC}_{50}$ value of $\mathbf{1}$ in the cell-based assay was $98.6 \mu \mathrm{M}$.

In the course of our screening for CD44 antagonists, 1 was isolated from the culture of Dacrymyces sp. SANK 20204. The structure of $\mathbf{1}$ was elucidated by physicochemical and spectral data analysis and decomposition experiments, and $\mathbf{1}$ was shown to be a new compound. $\mathbf{1}$ was mainly composed of two moieties, a trisaccharide moiety and a fatty acid moiety. Among known antibiotics, the structure of 1 resembles the structure of glykenins [23], including the trisaccharide moiety composed of two residues of xylose and one residue of glucose. The structural differences between $\mathbf{1}$ and glykenins were mainly found in the number of hydroxyl groups and acetyl groups. Glykenins were originally isolated from an unidentified basidiomycete [23]. After that, glykenin IV A was isolated from Dacrymyces stillatus [24]. We isolated here a new glykenin-related compound, F-19848 A, from a different Dacrymyces strain. Dacrymyces (Basidiomycota, Basidiomycetes) seemed to have the ability to produce a variety of glykenin-related compounds.

1 inhibited the cellular HA turn over. We previously reported novel inhibitors of CD44 binding. The compounds F-16438s inhibited the interaction between HA and CD44 in a cell free system, but did not show their inhibitory activity in cell levels [19]. $\mathbf{1}$ is the first reported lowmolecular weight inhibitor for the cellular CD44-HA interaction. The compound could be a good chemical probe for further elucidation of the functions of CD44-HA interaction in various cellular responses.

\section{Experimental}

\section{General Experimental Procedures}

The IR spectrum was obtained with a JASCO FT/IR-610 spectrometer. The UV spectrum was recorded on a Shimadzu UV-265FW spectrometer. The NMR spectra were recorded on a Bruker Biospin AVC500 spectrometer equipped with a cryogenic probe. The high resolution mass spectrum was recorded on a JEOL JMS-T100LC. The GC-MS spectra were recorded on a HP6890 Series GC System equipped with a column (Agilent Technologies DB-5, $0.25 \mathrm{~mm}$ i.d. $\times 15 \mathrm{~m}$ ) and a 5973 Mass Selective Detector.

\section{Investigation of the Fatty Acid Moiety of 1}

i) Methylation of $\mathbf{1}$

To the solution of $\mathbf{1}(10 \mathrm{mg})$ in DMSO $(2.6 \mathrm{ml})$ was added $\mathrm{NaOH}$ (130 mg). The mixture was stirred at room temperature for 20 minutes. Then, to the mixture was added methyl iodide $(900 \mu \mathrm{l})$ and it was stirred at room temperature for 3 hours. The methylated derivative was 
extracted by EtOAc and purified by a Sep-pak C18 cartridge (Waters), yielding $1.6 \mathrm{mg}$.

ii) Deglycosylation and Silylation of the Methylated Derivative

The $5.0 \% \mathrm{HCl}-\mathrm{MeOH}$ solution $(500 \mu \mathrm{l})$ was added to $0.5 \mathrm{mg}$ of the methylated derivative. The mixture was sealed to the ampule and heated at $70^{\circ} \mathrm{C}$ for 5 hours and then chilled to room temperature and dried in vacuo. The deglycosylated derivative was dissolved in pyridine $(120 \mu \mathrm{l})$. To the solution was added $\mathrm{N}, \mathrm{O}$ bis(trimethylsilyl)trifluoroacetamide (BS-TFA, $100 \mu \mathrm{l}$ ) and it was then analyzed by GC-MS.

\section{Identification of Glucose and Xylose}

The $S$-(+)-2-butanol/5.0\% $\mathrm{HCl}-\mathrm{MeOH}(1: 1)$ solution (200 $\mu \mathrm{l}$ ) was added to $1.0 \mathrm{mg}$ of $\mathbf{1}$ and treated as described above. Then the decomposition product was dissolved in pyridine $(400 \mu 1)$. To the solution was added BS-TFA $(400 \mu \mathrm{l})$ and it was then analyzed by GC-MS. Authentic samples (D-glucose, L-glucose, D-xylose and L-xylose) were treated and analyzed in the same way.

\section{CD44-HA Binding Assay}

The whole membrane fractions of CD44/293 cells and fluorescein conjugated HA (fl-HA) were used for the binding assay, as described previously [18]. CD44/293 cells, stably expressing human CD44 [16], were washed and harvested with PBS and disrupted by sonication in $0.2 \mathrm{M} \mathrm{NaCl}, 50 \mathrm{mM}$ Tris- $\mathrm{HCl}, \mathrm{pH}$ 7.8. The suspensions of the disrupted cells were centrifuged at $400 \mathrm{~g}$ for 5 minutes. Then, the supernatant was subjected to centrifugation at $20,000 \mathrm{~g}$ for 1 hour to yield high speed pellets. The membrane fractions were resuspended and adjusted to $100 \mu \mathrm{g} / \mathrm{ml}$ of protein in $0.2 \mathrm{M} \mathrm{NaCl}, 50 \mathrm{mM}$ Tris- $\mathrm{HCl}, \mathrm{pH}$ 7.8. The membrane fractions $(100 \mu \mathrm{l})$ were incubated with $0.1 \mu \mathrm{g}$ of fl-HA and various concentrations of F19849 A on a 96-well glass filter plate (GF/C hydrophobic, Whatman) at room temperature for 1 hour, then filtrated using a Multiscreen Vacuum Manifold (Millipore). After washing 6 times with $0.2 \mathrm{M} \mathrm{NaCl}, 50 \mathrm{mM}$ Tris-HCl, $\mathrm{pH} 7.8$ by filtration, $100 \mu \mathrm{l}$ of $0.3 \mathrm{M} \mathrm{NaOH}$ was added to each well. The fl-HA, binding to the CD44 on the plate was detected by an ARVO fluoroscan. Non-specific binding was determined in the presence of a large excess $(100 \mu \mathrm{g} / \mathrm{ml})$ of unlabeled hyaluronic acid.

\section{The Cell Based Assay for CD44-HA Binding}

The inhibitory activity of F-19848 A for CD44-HA binding in living cells was estimated from CD44-dependent HA degradation mediated by Hyal-2. Hyal-2/CD44/293 is a cell line stably expressing both Hyal-2 and CD44 as described previously [16]. The cells were plated on a 12-well type I collagen pre-coated plate at a density of $10^{6} /$ well and cultured for 48 hours as described previously [16]. The cells were then cultured in $1.0 \mathrm{ml}$ of the medium containing $3.0 \mu \mathrm{g} / \mathrm{ml} \mathrm{fl}-\mathrm{HA}$ and $50 \sim 200 \mu \mathrm{M}$ of $\mathbf{1}$ for 16 hours. After incubation, the conditioned medium was collected and characterized by size-exclusion chromatography using a $1.6 \mathrm{~cm} \times 10 \mathrm{~cm}$ Sepharose CL-2B column equilibrated with PBS. Fractions of $2.5 \mathrm{ml}$ were collected at $0.5 \mathrm{ml} /$ minute and the fluorescence (excitation, $485 \mathrm{~nm}$; emission, $535 \mathrm{~nm}$ ) was determined by an ARVO fluoroscan (PerkinElmer). The inhibitory activity of the compound was estimated from the amount of remaining high molecular weight fl-HA eluted in fractions 4 and 5 of the column. In the control experiment, fl-HA $(3.0 \mu \mathrm{g} / \mathrm{ml})$ was incubated with Hyal-2/CD44/293 cells with or without non-labeled HA $(1 \sim 27 \mu \mathrm{g} / \mathrm{ml})$ to obtain a calibration curve.

Acknowledgements We are deeply grateful to Dr. Toshio Takatsu for his useful advice.

\section{References}

1. Abatangelo G, O'Regan M. Hyaluronan: biological role and function in articular joints. Eur J Rheumatol Inflamm 15: 9-16 (1995)

2. Brandt KD, Smith GN Jr, Simon LS. Intraarticular injection of hyaluronan as treatment for knee osteoarthritis. What is the evidence? Arthritis Rheum 43: 1192-1203 (2000)

3. Dahl LB, Dahl IMS, Engström-Laurent A, Granath K. Concentration and molecular weight of sodium hyaluronate in synovial fluid from patients with rheumatoid arthritis and other arthropathies. Ann Rheum Dis 44: 817-822 (1985)

4. Ghosh P. The role of hyaluronic acid (hyaluronan) in health and disease: interactions with cells, cartilage and components of the synovial fluid. Clin Exp Rheumatol 12: 75-82 (1994)

5. Toole BP. Hyaluronan in morphogenesis. Semin Cell Dev Biol 12: 79-87 (2001)

6. Toole BP. Hyaluronan: from extracellular glue to pericellular cue. Nat Rev Cancer 4: 528-539 (2004)

7. Lesley J, Hyman R, Kincade PW. CD44 and its interaction with extracellular matrix. Adv Immunol 54: 271-335 (1993)

8. Picker LJ, Nakache M, Butcher EC. Monoclonal antibodies to human lymphocyte homing receptors define a novel class of adhesion molecules on diverse cell types. J Cell Biol 109: 927-937 (1989)

9. Bourguignon LYW, Lokeshwar VB, He J, Chen X, Bourguignon GJ. A CD44-like endothelial cell transmembrane glycoprotein (GP116) interacts with extracellular matrix and ankyrin. Mol Cell Biol 12: 
4464-4471 (1992)

10. Zhu D, Bourguignon LYW. Overexpression of CD44 in p185(neu)-transfected NIH3T3 cells promotes an upregulation of hyaluronic acid-mediated membranecytoskeleton interaction and cell adhesion. Oncogene 12: 2309-2314 (1996)

11. Brown TA, Bouchard T, St John T, Wayner E, Carter WG. Human keratinocytes express a new CD44 core protein (CD44E) as a heparan-sulfate intrinsic membrane proteoglycan with additional exons. J Cell Biol 113: 207-221 (1991)

12. Grover J, Roughley PJ. Expression of cell-surface proteoglycan mRNA by human articular chondrocytes. Biochem J 309: 963-968 (1995)

13. Culty M, Nguyen HA, Underhill CB. The hyaluronan receptor $(\mathrm{CD} 44)$ participates in the uptake and degradation of hyaluronan. J Cell Biol 116: 1055-1062 (1992)

14. Hua Q, Knudson CB, Knudson W. Internalization of hyaluronan by chondrocytes occurs via receptor-mediated endocytosis. J Cell Sci 106: 365-375 (1993)

15. Tammi R, Rilla K, Pienimaki JP, MacCallum DK, Hogg M, Luukkonen M, Hascall VC, Tammi M. Hyaluronan enters keratinocytes by a novel endocytic route for catabolism. J Biol Chem 276: 35111-35122 (2001)

16. Harada H, Takahashi M. CD44-dependent intracellular and extracellular catabolism of hyaluronic acid by hyaluronidase-1 and -2. J Biol Chem 282: 5597-5607 (2007)

17. Turley EA, Noble PW, Bourguignon LY. Signaling properties of hyaluronan receptors. J Biol Chem. 277: 4589-4592 (2002)

18. Harada H, Nakata T, Hirota-Takahata Y, Tanaka I, Nakajima M, Takahashi M. F-16438s, novel binding inhibitors of CD44 and hyaluronic acid. I. Establishment of an assay method and biological activity. J Antibiot 59: 770-776 (2006)

19. Hirota-Takahata Y, Harada H, Tanaka I, Nakata T, Nakajima M, Takahashi M. F-16438s, novel binding inhibitors of CD44 and hyaluronic acid. II. Producing organism, fermentation, isolation, physico-chemical properties and structural elucidation. J Antibiot 59: 777-784 (2006)

20. McNabb RFR. Taxonomic studies in the Dacrymycetaceae VIII. Dacrymyces Nees ex Fries. New Zealand J Bot 11: 461-524 (1973)

21. Gerwig GJ, Kamerling JP, Vliegenthart JFG. Determination of the $\mathrm{D}$ and $\mathrm{L}$ configuration of neutral monosaccharides by high-resolution capillary G.L.C. Carbohydr Res 62: 349-357 (1978)

22. Bauer W, Soi A, Hirsch A. Application of DPFGSE-ROE to calixarene derivatives under conditions near NOE zerocrossing. Magn Reson Chem 38: 500-503 (2000)

23. Nishida F, Mori Y, Isobe S, Furuse T, Suzuki M, Meevootisom V, Flegel TW, Thebtaranonth Y. Structures of deacetyl glykenins-A, B, and C, glycosidic antibiotics from Basidiomycetes sp. Tetrahedron Lett 29: 5287-5290 (1988)

24. Mierau V, Anke T, Sterner O. Dacrymenone and VM 32982-New antibiotics with antibacterial and antifungal activity. Z Naturforsch 58c: 541-546 (2003) 